\title{
IDENTIFICATION AND DELIMITATION OF AREAS IN NEED \\ OF NATURE-BASED SOLUTIONS. AN APPROACH BASED ON THE QUALITY OF SPACE IN THE CONTEXT OF CULTURAL HERITAGE IN KRAKOW
}

\author{
Barbara Olczak $^{1 \bowtie}$, Magdalena Wilkosz-Mamcarczyk ${ }^{2}$, Nadiya Sosnova ${ }^{3}$ \\ 1 Department of Ornamental Plants and Garden Art, University of Agriculture in Krakow, al. 29 Listopada 54, 31-425 Kraków \\ 2 Department of Land Management and Landscape Architecture, University of Agriculture in Krakow, al. 29 Listopada 54, \\ 31-425 Kraków \\ 3 Department of Urban Planning and Design, Lviv Polytechnic National University, Lviv
}

\begin{abstract}
Aim of the study

The paper focuses on the introduction of nature-based solutions (NBS) into modern cities to control and counteract effects of climate change. The focal point was highly urbanised historic areas. The research was conducted in Kraków, the second-largest city in Poland, the development of which has been inherently entwined with the local fluvial network.
\end{abstract}

\begin{abstract}
Material and methods
Historical analyses helped demonstrate that the fluvial network of Kraków is an interesting albeit forgotten part of its heritage, often obscured by the traditional, rich cultural heritage of the city. Not only did the fluvial network play an essential role in the growth of the city, but it has also been part of the every-day life of its citizens and an increasingly important factor in improving the quality of life. Still, the flood risk it entails is aggravated by climate change. We analysed modern trends regarding the adaptation of cities to climate change and global NBS. We employed an in-depth map analysis to identify zones in the city where NBS has to be improved. The next step was to locate and characterise NBS components in the city with in situ studies.
\end{abstract}

\section{Results and conclusions}

The results suggest that the awareness of city administration and residents regarding preventing the negative effects of climate change has grown. Nevertheless, it is necessary to conduct integrated interdisciplinary activities in order to prepare Kraków for the changes to come and improve the quality of space and life while emphasising its heritage. The paper found justification for the integration and development of green and blue projects in Kraków.

Keywords: cultural heritage, life quality, space quality, nature-based solutions (NBS), fluvial network 


\section{INTRODUCTION}

\section{Research objective and hypothesis}

As Polish cities grow more urbanised, their landscape water retention capacity - the ability to retain precipitation in place - diminishes. Climate change, along with the extreme weather events it causes - such as droughts, floods, or extremely high temperatures - render conventional water management systems insufficient to face new ecological, economic, and social challenges. These changes kindled a perception pivot regarding rainwater management and water retention in cities (Krauze et al., 2010; Perrotti, 2020). Regrettably, the typical Polish approach still focuses mostly on draining it as fast as possible. As heavy rains grow in frequency, the sewage system cannot handle all the water during an extreme event. Continuous urban fabric, impervious surfaces, and increased water consumption all push water table down. It leads to desiccation and degradation of the ground and settlement of soil up to several metres. The promotion of green areas and NBS in cities would help control extreme events' risk and consequences. Therefore, the introduction of BGI systems and solutions into cities should be among today's greenery management priorities, and they should be included in design and implementation of new projects. The question today is not whether, but how to introduce NBS.

NBS help restore functional biospheres. They ensure clean water, improve biodiversity, and prepare the city for climate change effects, while providing social functions and contact with nature for better physical and mental health. It is the duty of public administration, legal persons, and other organisations as well as individuals to nurture the natural environment as national heritage and treasure. It is believed that NBS, be they systemic, city-wide projects or local spot interventions, should do more than handle one aspect, such as water retention. They should improve the quality of urban space in harmony with its character, while respecting nearby cultural heritage.

Thanks to its history, Kraków boasts exceptional cultural heritage entwined with the urban fabric of the second-largest city in Poland (see: Fig. 1). History interweaving with the new in a vibrant city poses a significant challenge to the introduction of NBS.

Interestingly, its fluvial network is, in a way, part of the cultural-natural heritage of Kraków. The hy- dro-node of the Vistula, Rudawa, Prądnik, Dłubnia, and Wilga was a natural factor promoting the city's establishment and economic growth (Mitkowski, 1955; Pociask-Karteczka, 1994). The introduction of NBS may contribute to the restoration, remembrance, and reinforcement of the role of water and greenery in the city.

According to a report by the European Environment Agency on air quality in Europe, in 2016, PM10 concentration above the annual limit value of $40 \mu \mathrm{g} \mathrm{m}$ was recorded in $6 \%$ of reporting stations, including 29 stations in Poland. Poland was third to last in terms of PM10 concentration in 2016. As regards PM2.5, it came fourth to last in a list of thirty-nine analysed countries, even though pollution in Poland dropped in 2016 compared to 2011 (EEA Report, 2016). The study shows that air particulate matter pollution is a significant problem in Poland. Poor air quality contributed to an increased fatality rate in Poland in recent years (Analysis, 2018). Actions taken, such as the clean air resolution in Kraków, are beginning to produce results. Nevertheless, air stagnation caused by the geographical situation of Kraków in a valley and building-up of ventilation corridors make the air quality unsatisfactory in autumn and winter.

Poland faces the issue of insufficient water resources. This is why participants of the Economy of a Water City Conference in 2018 recommended that Polish cities should strive to make NBS more popular. 'Green' city thinking is no longer 'in'. Today, water is considered not only a raw material but also an important component of growth as well as a part of the landscape, culture, and economy. Greenery, the other bluegreen infrastructure element, is a more straightforward association when thinking about the quality of urban space. The introduction of water surrounded by greenery improves the city's allure. Still, it also has a more comprehensive impact on its development, quality of its space, and quality of life there. Water in the city can shift the perception of the urban environment towards symbolism. It can be part of the genius loci emerging from the history of the city and its heritage (Hausner et al., 2019, Olczak, 2019).

Rain is a primary source of fresh water on Earth as well as a cause of natural disasters such as flash flooding in cities. Among the causes of the latter are climate change, growing urban populations, and city devel- 

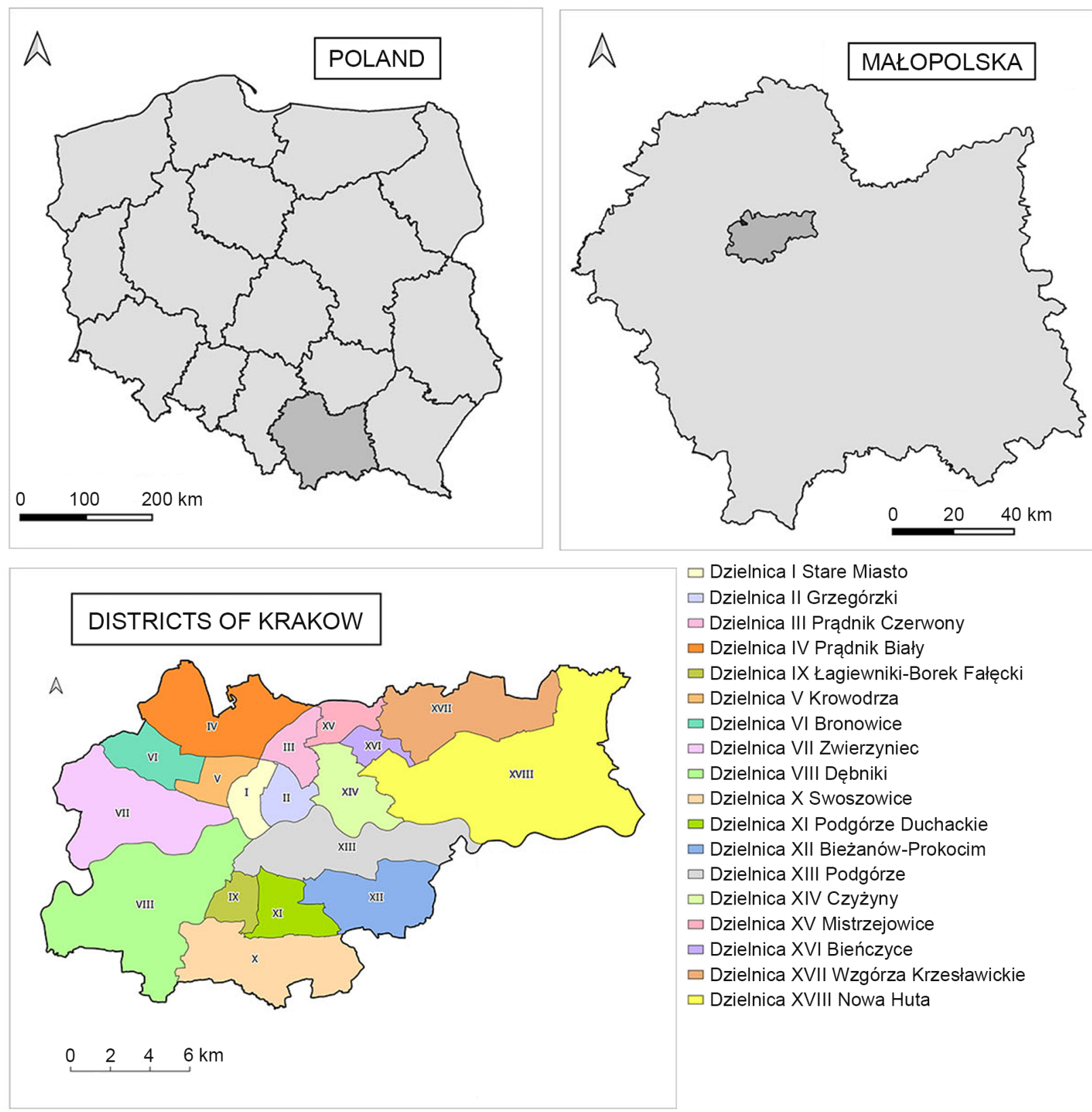

$\square$ Dzielnica I Stare Miasto $\square$ Dzielnica II Grzegórzki $\square$ Dzielnica III Prądnik Czerwony $\square$ Dzielnica IV Prądnik Biały $\square$ Dzielnica IX Łagiewniki-Borek Fałęcki $\square$ Dzielnica V Krowodrza $\square$ Dzielnica VI Bronowice $\square$ Dzielnica VII Zwierzyniec $\square$ Dzielnica VIII Dębniki $\square$ Dzielnica X Swoszowice $\square$ Dzielnica XI Podgórze Duchackie $\square$ Dzielnica XII Bieżanów-Prokocim $\square$ Dzielnica XIII Podgórze $\square$ Dzielnica XIV Czyżyny $\square$ Dzielnica XV Mistrzejowice $\square$ Dzielnica XVI Bieńczyce $\square$ Dzielnica XVII Wzgórza Krzesławickie $\square$ Dzielnica XVIII Nowa Huta

Fig. 1. Research area location. Source: own study

opment leading to land-cover change (Mustafa et al. 2019). In rural areas, about $90 \%$ of rainwater contributes to the local water balance through infiltration, interception, evaporation or soil water retention. The impervious urban surface is a barrier for water, which runs off to the already overflowing storm drains, lead- ing to flash floods and floods. The runoff causes water deficit, as $70-90 \%$ of water is irretrievably lost (Wagner I et al., 2013).

The paper's objective is to present the issue of introducing water into urban space through the NBS, to expound its role in improving the quality of space 
and quality of life, and to delimit areas in the city most in need of such interventions due to various kinds of pollution. The article expands on the need to introduce modern solutions into compact urban tissue, while respecting cultural heritage. We intend to highlight the fact that protection of cultural heritage can coincide with new technologies, and the introduction of NBS into historic sites can improve their perception without any damage to heritage. The present paper investigates solutions, which prove that cultural heritage does not need to be a barrier in this regard. On the contrary, heritage sites embedded in the city's history may assume new functionalities and better quality of space, fit for a modern city and its users, residents and tourists alike.

Apart from hydraulic engineering structures, which are important for any city with an extensive fluvial network, it is vital to increase the share of and protect from development the vegetated areas that slow down water flow, reduce runoff, and retain water, such as polders, dry retention basins, green areas, and land with the soil of substantial water capacity, mainly peat or sapric. Small water retention, which is the effort to extend water cycle duration, can prepare modern cities for the consequences of climate change (http://klimada.mos.gov.p1/?p=163).

\section{MATERIAL AND METHODS}

The present research is a case study of Kraków within its city boundaries. The first stage entailed desk research on primary sources focused on globally applied NBS, their role in mitigating climate change consequences, and factors detrimental to the quality of life, such as air quality. Then, we delimited those areas in the city, which are in need of NBS, using map analysis.

The second stage was to indicate NBS projects, which demonstrated that care for cultural heritage could be combined with the effort to improve space and life quality. Objects related to the city's history, not only historic sites but also the fluvial network interwoven with developments that are the historical component of the city, could have their spatial quality and functionality redefined to meet the needs of the contemporary resident and tourist.

We propose to install NBS in areas that are the most problematic in order to harness their complete potential. Such areas for Kraków were delimited by identifying zones with:

- the mean annual concentration of PM10 over $40 \mu \mathrm{g} / \mathrm{m}^{3}$ (EEA Report, 2018);

- noise from rail or road vehicles exceeding $60 \mathrm{~dB}$ (Regulation... 2012);

- risk of heat islands. As the urban heat island effect is very dynamic, we considered temperature over $38^{\circ} \mathrm{C}$ on 7 August 2013, 9:35 a.m. (Walawander, 2015) (see: Fig. 2).

The result of the analyses was complemented with areas suffering from a shortage of public green spaces in compact developments in the second stage (Development Directions... 2019; Areas with public greenery shortage), and urbanised areas at risk of a hundred-year flood Q1\% as a result of direct channel overflow according to flood hazard plan (2030 Climate Adaptation Plan..., see: Appendix No. 2). The research delimited the zones where NBS was much needed, focusing particularly on the immediate vicinity of cultural heritage (see: Fig. 3).

The presented methods for investigating the positioning of nature-based solutions can be complemented with other conditions related to the nature of the locations to ensure a more precise selection of areas where NBS should be introduced. Particularly beneficial results could be expected when these are combined with an innovative decision support system (DSS) providing users with locations of urban drainage basins. The system based on a multi-aspect methodology takes into account weather and soil conditions. It indicates green areas suitable for green infrastructure that are optimal regarding rainwater retention and storage (Kazak et al., 2018). A comprehensive approach to the delimitation of areas and selection of NBS to suit a specific location can become a tool kit serving to support administrative effort to expand NBS.

\section{RESULTS AND DISCUSSION}

The literature divides components of NBS most commonly used to mitigate climate change consequences and improve the quality of space in urban areas into two categories. The first one is systemic solutions, also referred to as a NBS network implemented in an entire locality. Network solutions introduce so-called green streets to cities. Street trees have a significant 


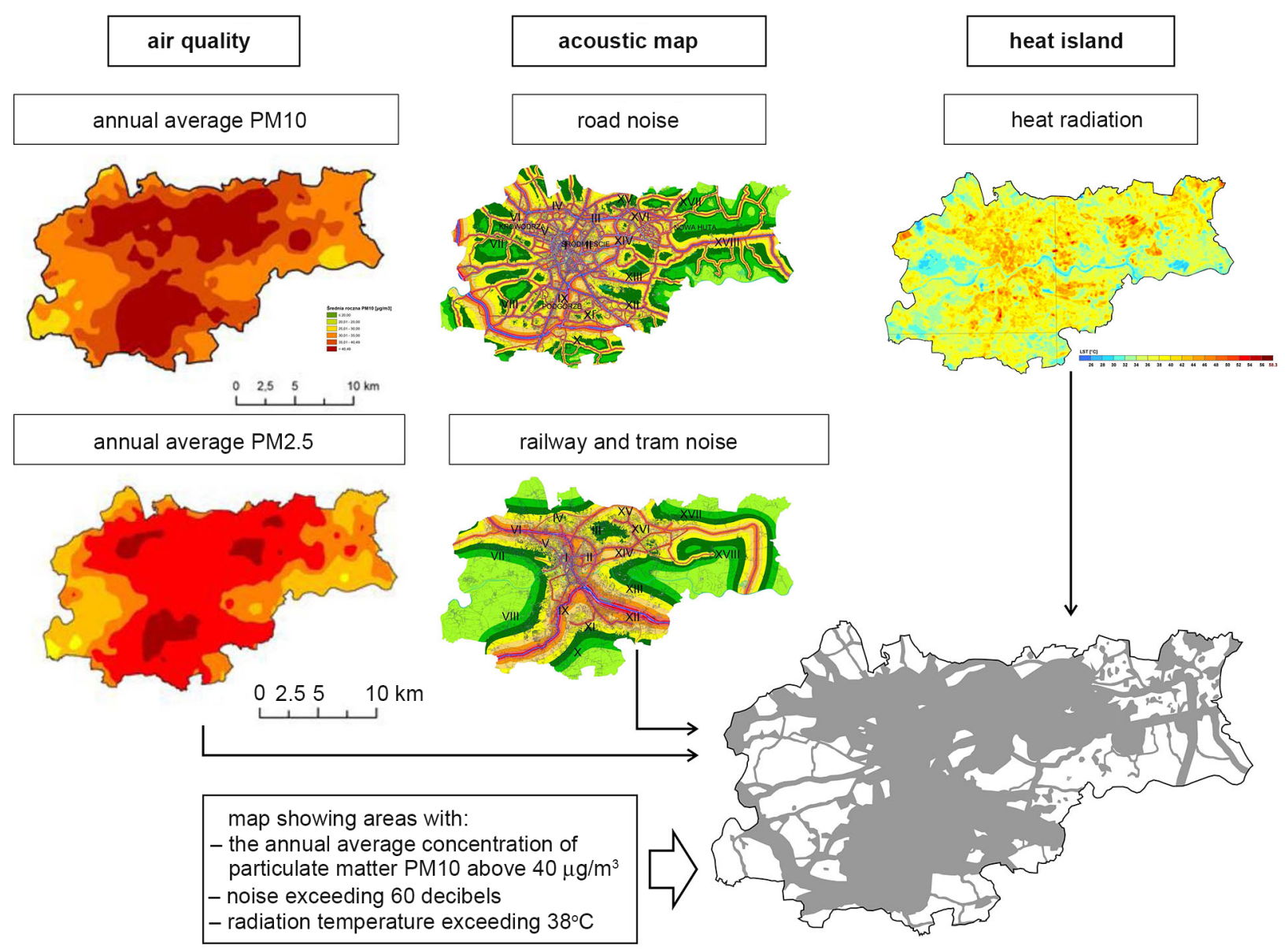

Fig. 2. Delimitation of problem areas, stage 1. Source: own study

impact on rainwater management in cities. They can minimise the effect of development on the water cycle. The use of natural processes to manage water reduces the costs of traditional grey infrastructure. Green streets control and facilitate the flow of rainwater by combining permeable surfaces, vegetation, and soil. The goal is to filter pollution and slow down infiltration to improve water quality, reduce erosion, and recharge groundwater (Sabbion, 2018). Other network solutions include green buffer belts, integration of existing green areas into networks, or systems of spot solutions. Spot solutions among urban tissue are the other category of NBS. They include green roofs, green walls, retention ponds, rain gardens, stormwater reservoirs, grassed swales, infiltration trenches, infiltration areas, soakaways, water retention structures around trees, surface infiltration reservoirs, detention tanks, and drainage tunnels. Their primary role is to harvest water in situ. This way, water can be retained, if possible, to be later used during dry spells (Adamowski et al., 2017; Lejcuś et al., 2017). Prevention of adverse urbanisation factors can employ solutions for which studies exist that confirm the effectiveness of porous paving in urban settings, which ameliorate the urban heat island effect and help preserve biological activity of the soil, leading to improved health of urban tree species (Finia et al., 2017).

The next stage was a field survey. Site visits in 2020 identified NBS within Kraków city limits. The fieldwork (see: Table 1) suggests that the most popular NBS are green roofs and green walls on buildings of various functions. Green belts of wildflower meadows in the 


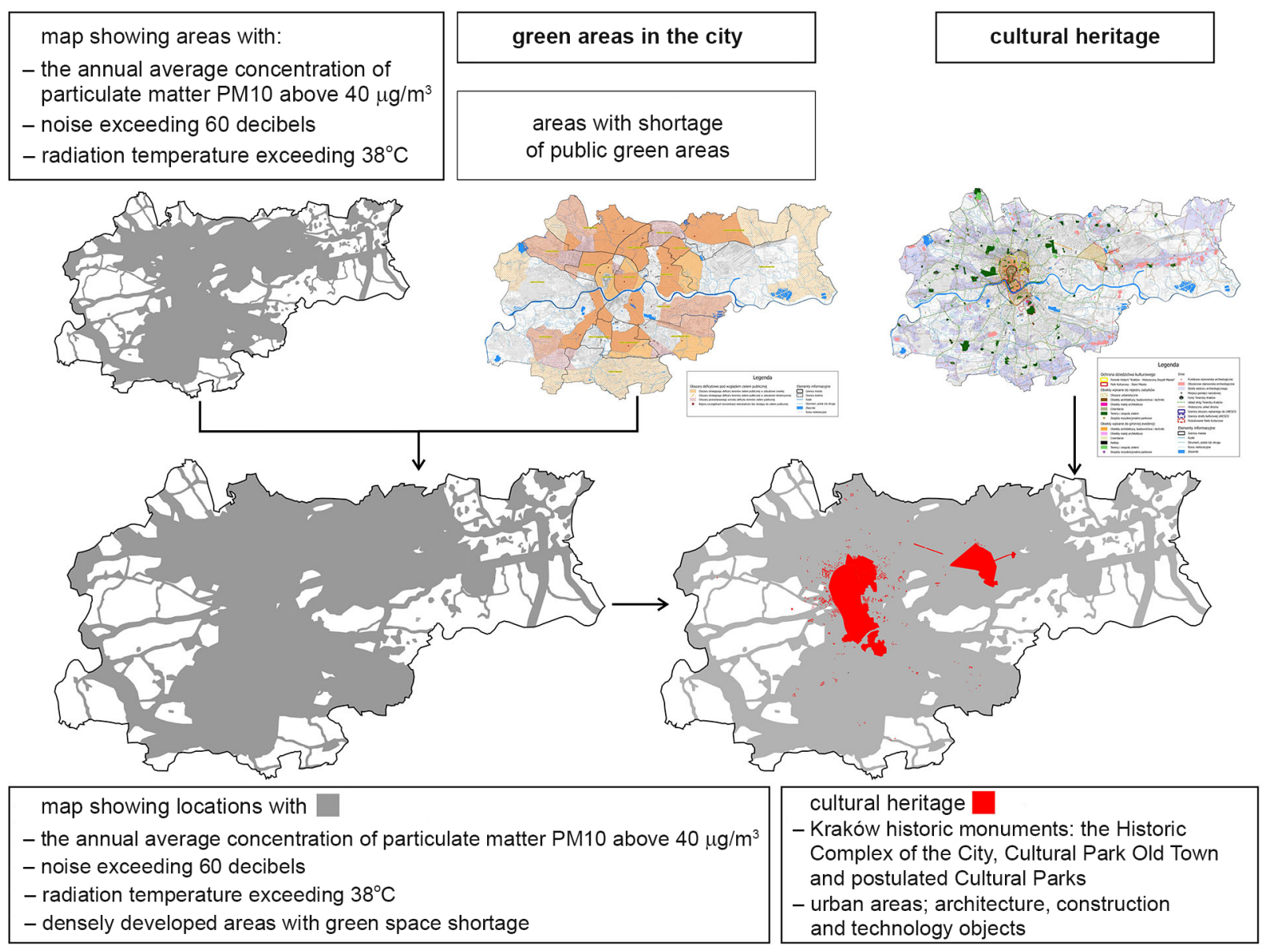

Fig. 3. Delimitation of problem areas, stage 2. Source: own study

right-of-way and green tram tracks are popular as well. Kraków has $28 \mathrm{~km}$ of such trackage, $13 \%$ of total trackage in the city (transport-publiczny.pl). The number of various spot solutions in the city grows. This indicates a growing awareness of the need for NBS among administration and residents, who propose NBS projects as grassroots participatory budget candidates.

Subject literature suggests that the 20th-century knowledge specialisation led to the separation of urban planning and water management competencies. Problems with water brought about a pivot in the perception of urban water issues in the early 21 st century. The problems were of qualitative character, such as pollution, and some were quantitative in nature, for example, droughts or floods. Today, the water management paradigm changes, focusing on water resource management (Shannon, De Maulder 2008 quoted from Januchta-Szostak 2019). The global popularity of NBS is on the rise. Positive changes appear at the national level as well. The greatest hope for the improvement in the quality of life and space in Polish cities comes from network NBS employed in Łodź (Krauze et al., 2010). The most prominent among them is the MPA - Miejskie Plany Adaptacji, urban plans for adaptation to climate change, implemented in thirty-seven Polish cities with more than 100,000 residents (including Kraków), three cities with more than 90,000 residents, and four cities with functional ties with other cities of more than 100,000 people - in the Upper Silesian conurbation and Tri-city agglomeration. The project's priorities are to reinforce the resilience of the cities against torrential rains and floods as 
Table 1. Blue-green infrastructure in Kraków

\begin{tabular}{|c|c|c|}
\hline & Type & Example \\
\hline \multirow{7}{*}{\multicolumn{2}{|c|}{ 1. Green roof }} & 1. Kraków John Paul II International Airport building \\
\hline & & 2. A hotel building near Kraków John Paul II International Airport \\
\hline & & 3. Sports Hall of the University of Agriculture, Aleja 29 Listopada \\
\hline & & 4. Cracovia Sports Hall, Aleja Focha \\
\hline & & 5. Environmental Education Centre, Polana Lea (meadow) \\
\hline & & 6. Multi-family residential buildings, e.g. in Kalwaryjska street \\
\hline & & 7. Garages, e.g. in Poznańska street, Opolska Bussines Park, Lublańska street \\
\hline & Retention pond & 1. Park Lotników Polskich \\
\hline \multirow{2}{*}{\multicolumn{2}{|c|}{ 3. Rain garden }} & 1. Near the Bronowice shopping mall \\
\hline & & 2. Near the library on the Osiedle Teatralne (housing estate) \\
\hline & Ground rain garden & 1. Park Stacja Wisła \\
\hline \multirow{2}{*}{\multicolumn{2}{|c|}{ 5. Green walls }} & 1. Residential buildings, e.g. in the streets of Św. Anny, Poznańska \\
\hline & & 2. Public utility, office, and commercial buildings, e.g. Rondo Młyńskie (roundabout), \\
\hline & Green tram tracks & 1. South of Rondo Grzegórzeckie (roundabout) \\
\hline & Permeable surfaces & $\begin{array}{l}\text { 1. Park Tysiąclecia } \\
\text { 1. Car park in Lublańska street }\end{array}$ \\
\hline \multirow{4}{*}{\multicolumn{2}{|c|}{ 8. Green bus/tram stops }} & 1. Near the ICE Congress and Entertainment Centre \\
\hline & & 2. Near Teatr Ludowy \\
\hline & & 3. Rondo Grzegórzeckie \\
\hline & & 4. Mickiewicza Avenue, near AGH University of Technology and University of Agriculture \\
\hline & \multirow{2}{*}{$\begin{array}{l}\text { Structures for storing } \\
\text { water around trees }\end{array}$} & 1. Plac św. Ducha (square) \\
\hline & & 2. Park Czyżyny \\
\hline \multirow{2}{*}{\multicolumn{2}{|c|}{10 Wildflower meadows }} & $\begin{array}{l}\text { 1. Parks, e.g. Park Stacja Wisła, Park Lotników Polskich, Park Jordana, Park Aleksandry, Park } \\
\text { Tysiąclecia, Błonia }\end{array}$ \\
\hline & & $\begin{array}{l}\text { 2. Green belts near traffic routes and tram tracks, e.g. the streets of Aleja Pokoju, Aleja } \\
\text { Powstania Warszawskiego, Nowohucka, Stella-Sawickiego }\end{array}$ \\
\hline
\end{tabular}

well as improve natural retention capabilities (http:// klimada.mos.gov.pl/projekt-mpa/).

As illustrated here with examples from Kraków (see: Fig. 4), spot solutions demonstrate that the way people think about water in urban spaces is changing. The change is apparent in the administration officials, designers, and residents, who often initiate such projects under participatory budget schemes.

Figure 4 shows existing NBS.

\section{CONCLUSIONS}

The desk research demonstrates the capabilities of modern technology and environmental approach to BGI design. Examples from all over the world provide diversity in terms of form, function, size, and adaptation to specific needs. The abundance of knowledge that experts share in their papers, guides to NBS, or relevant websites suggests that the domain grows rapidly. It 


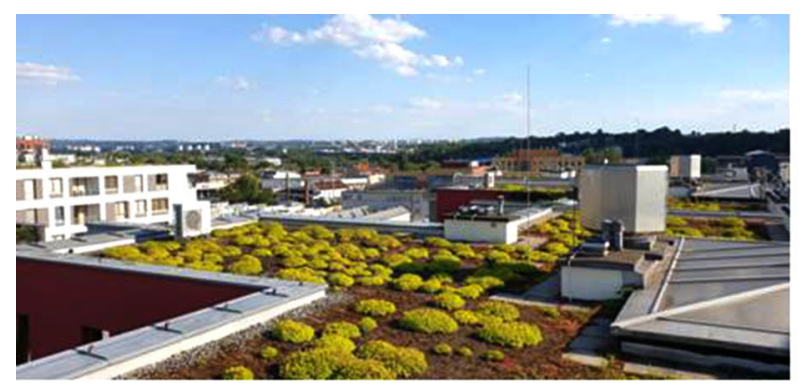

1. Roof of a residential building, Kalwaryjska street

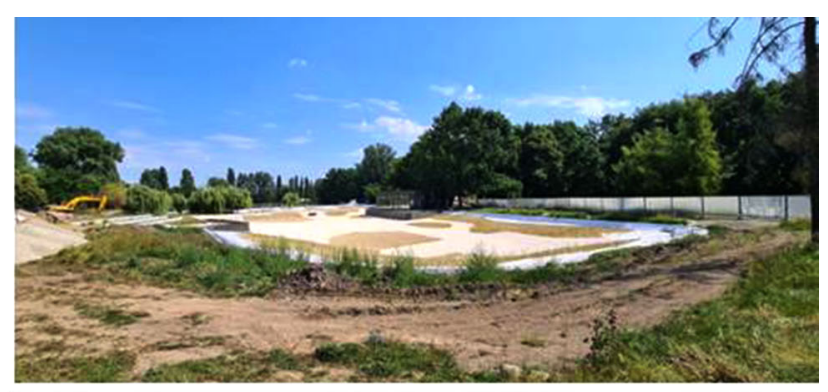

2. Retention pond, Park Lotników Polskich
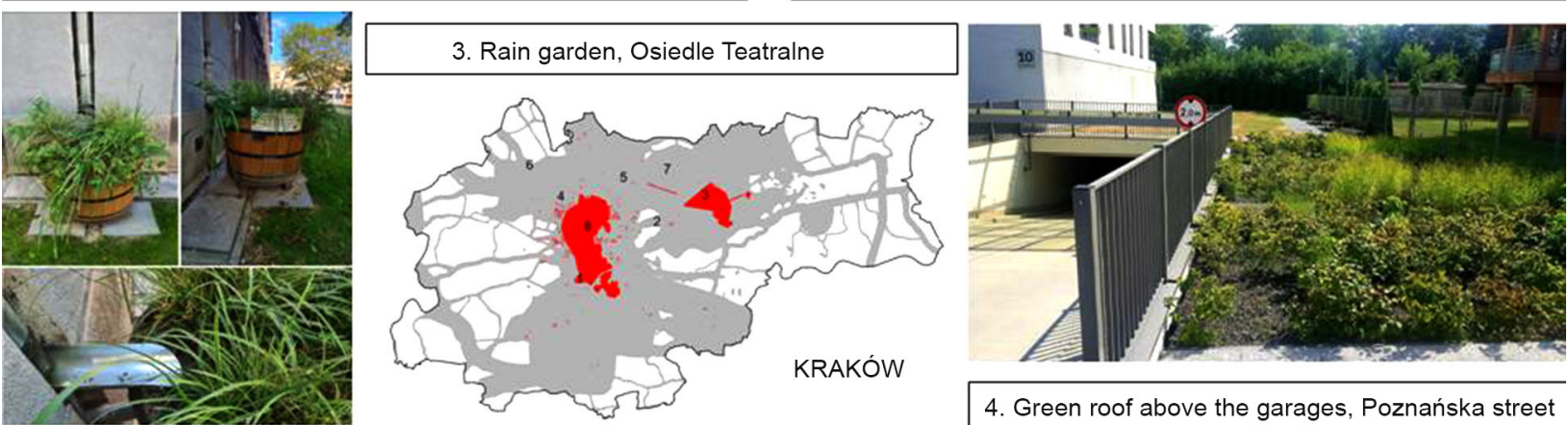

4. Green roof above the garages, Poznańska street

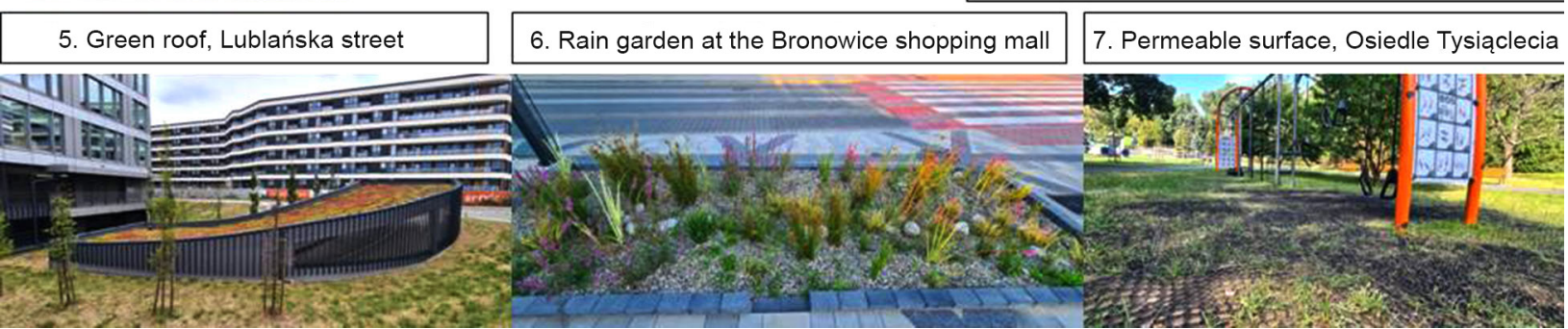

Fig. 4. The diversity of BGI solutions in Kraków. Source: own study

gives us hope that the presence of NBS - systemic ones in particular - in Polish cities will continue to grow. If introduced in harmony with urban cultural heritage assets and their surroundings, NBS can contribute to the new functionality of public space as well as the quality of life and space that residents of 21 st-century cities need. To promote the growth of NBS, we propose:

- to introduce regulations supporting systemic NBS in high-level spatial planning documents, such as zoning conditions and directions;

- to introduce regulations supporting systemic and spot NBS in low-level spatial planning documents, such as local zoning plans;

- to incorporate the areas in need of NBS, particularly near cultural heritage sites, into the Concept for a System of Public Green Spaces in Kraków (2019-2030 Directions of Development and Management of Green Spaces in Kraków);

- to develop standards for NBS formation and handbooks for municipalities on the rational use of water resources in urban environments;

- to hold workshops for public administration and the general public aimed at promoting NBS;

- to support grassroots initiatives for NBS;

- for urban planners and water management officers to cooperate in developing long-term solutions integrating the role of water and needs of people and nature;

- to include the historic town in the metropolis of the future, as a smart, liveable city, through smart use of water resources; 
- to draw on the historical natural heritage of fluvial network and greenery through the implementation of NBS.

Future research can include delimitation of areas with limited access to greenery and areas with public greenery shortage in the city as well as identification of places where NBS should be implemented first

\section{REFERENCES}

2030 Climate Adaptation Plan for the City of Kraków, Appendix No. 2 Main climate threats to the city and their derivatives, Source: https://www.bip.krakow.pl/zalaczniki/dokumenty/n/248571/karta

Adamowski, D., Zalewski, J., Paluch, P., Glixelli, T. (2017). Katalog zielono-niebieskiej infrastruktury. Cz. II. Wytyczne i rozwiązania. Budowa i przebudowa kanalizacji deszczowej i dostosowanie sieci kanalizacji deszczowej do zmian klimatycznych na terenie miasta Bydgoszczy, Miejskie Wodociągi i Kanalizacja w Bydgoszczy.

Analiza przyczyn wzrostu liczby zgonów w Polsce w 2017 roku, Departament Analiz i Strategii, Narodowy Fundusz Zdrowia (2018) nfz.gov.pl

Air quality in Europe - 2018 report, EEA Report No 12/2020, 26-34 retrived from: https://www.eea.europa. eu/publications/air-quality-in-europe-2018

Finia, A., Frangib, P., Moria, J., Donzellic, D., Ferrnini, F. (2017) Nature based solutions to migrate soil sealing in urban areas: Results form a 4-year study comparing permeable, porous, and impermeable pavements, Environmental Research, 156, 443-454.

Hausner, J., Kundzewicz, Z., Zaleski, J. (Eds.) (2019). Miasto - Woda - Jakość życia Open Eyes Economy Discussion Papers, Fundacja Gospodarki i Administracji Publicznej, Kraków, 7-9.

Januchta-Szostak, A. (2019) Strategie zintegrowanego zarządzania przestrzenią i wodą w miastach [In:] Hausner J., Kundzewicz Z., Zaleski J. (Eds.) (2019). Miasto Woda - Jakość życia Open Eyes Economy Discussion Papers, Fundacja Gospodarki i Administracji Publicznej, Kraków, 11-13.

Kazak, J. K., Chruściński, J., Szewrański, S. (2018) The development of a novel decision support system for the ocation of green infrastructure for stormwater management. Sustainability, 10, 4388. http://doi.org/10.3390/ su10124388
Kierunki Rozwoju i Zarządzania Terenami Zielonymi w Krakowie na lata 2019-2030, źródło: https://www.bip.krakow.pl/?dok_id=115410

Krauze, K., Żelewski, Ł., Włodarczyk, R. (2010). Rola Zieleni Miejskiej w Mieście Przyszłości - Błękitno-Zielona Sieć Łodzi. Acta Universitatis Lodziensis Folia Biologica et Oecologica, 3, 10-17.

Lejcuś, K., Burszta-Adamiak, E., Dąbrowska, J., Wróblewska, K., Orzeszyna, H., Śpitalniak, M., Misiewicz, J. (2017). Katalog dobrych praktyk - zasady zrównoważonego gospodarowania wodami opadowymi pochodzącymi z nawierzchni pasów drogowych, Wydział Inżynierii Miejskiej, Wrocław, 12, 37-98.

Mitkowski, J. (1955) Lokacja Krakowa i powstanie układu urbanistycznego miasta, [In:] Ochrona Zabytków 8/3 (30), $151-160$

Mustafa Andam, M., Muhammed Hadi, H., Szydłowski, M. (2019) Extreme raifalls as a cause of urban flash floods; a case study of the Erbil-Kudistan region of Iraq, Acta Sci. Pol. Formatio Circumiectus, 18(3), 113-132.

Olczak, B. (2019). The Quality of Space of the Place of Residence in the View of the Problems of the Modern City, Landscape Architecture 1, 23

Perrotti, D. (2020). Urban metabolism: old challenges new frontiers, and the research agenda ahead [In:] Verma, P., Singh, P., Raghubanshi, A.S., Rishikesh, S. (Eds.) Elsevier, Cambridge, MA, 3-8

Pocisk-Karteczka, J. (1994) Przemiany stosunków wodnych na obszarze Krakowa, Zeszyty Naukowe Uniwersytetu Jagiellońskiego MCXLIV Prace Geograficzne, 96

Rozporządzenie Ministra Środowiska z dnia 1 października 2012 r. zmieniające rozporządzenie w sprawie dopuszczalnych poziomów hałasu w środowisku Dz.U. 2012 poz. 1109,2

Sabbion P. (2018) Green Streets to Improve Water Management, Chapter 3.12. in Nature Based Strategies for Urban and Building Sustainability, 215-225

https://www.transport-publiczny.pl/wiadomosci/krakow-liderem-zielonych-torowisk-jakie-sa-ich-zalety-52830.html

Wagner I., Krauze K., Zalewski M., (2013) Błękitne aspekty zielonej infrastruktury, Zrównoważony Rozwój - Zastosowania, 4.

Walawender J.P. (2015) Miejska wyspa ciepła - negatywne skutki urbanizacji oraz możliwości przeciwdziałania (na przykładzie Krakowa), serwis internetowy Zielona Infrastruktura http://zielonainfrastruktura.pl 


\section{IDENTYFIKACJA I DELIMITACJA OBSZARÓW WYMAGAJĄCYCH WPROWADZENIA ROZWIAZZAŃ OPARTYCH NA NATURZE - PODEJŚCIE OPARTE NA JAKOŚCI PRZESTRZENI I DZIEDZICTWIE KULTUROWYM W KRAKOWIE}

\section{ABSTRAKT}

\section{Cel pracy}

Artykuł dotyczy wprowadzania rozwiązań opartych na naturze (NBS) do współczesnych miast w celu kontroli i przeciwdziałania skutkom zmian klimatu. Punktem centralnym były silnie zurbanizowane obszary historyczne. Badania przeprowadzono w Krakowie, drugim co do wielkości polskim mieście, którego rozwój łączył się bezpośrednio z istniejącą siecią rzeczną na wskazanym terenie. Pierwsza część badań dotyczyła delimitacji obszarów miasta, w których wprowadzanie elementów NBS powinno być traktowane jako priorytetowe.

\section{Materiat i metody}

Analizy historyczne pomogły unaocznić, iż poza bardzo bogatym dziedzictwem kulturowym Krakowa w ujęciu tradycyjnym, bardzo ciekawym i zapomnianym dziedzictwem miasta jest sieć rzeczna, która nie tylko odegrała ważną rolę w rozwoju miasta, ale towarzyszy mieszkańcom na co dzień i odgrywa coraz większą rolę w kształtowaniu wysokiej jakości przestrzeni życia. Wciąż jednak związane z nią ryzyko powodziowe jest potęgowane przez zmiany klimatyczne. Przeanalizowano współczesne trendy w adaptacji miast do zmian klimatu oraz stosowane rozwiązania z zakresu NBS w ujęciu światowym. Równocześnie na podstawie przeprowadzonych pogłębionych analiz kartograficznych wytypowano obszary miasta, w których konieczne jest rozwinięcie NBS na jego terenie. Następnie w ramach przeprowadzonych badań in situ zlokalizowano i scharakteryzowano elementy NBS na terenie miasta.

\section{Wyniki i wnioski}

Otrzymane wyniki wskazują, że z roku na rok świadomość władz miasta oraz mieszkańców dotycząca przeciwdziałania negatywnym konsekwencjom zmian klimatu wzrasta, jednak potrzebne jest prowadzenie zintegrowanych, interdyscyplinarnych działań, które przygotują Kraków na zachodzące zmiany, jak również podniosą jakość przestrzeni i jakość życia, z równoczesnym podkreśleniem jego dziedzictwa. Dodatkowo artykuł uzasadnia działania polegające na integracji projektów zieleni i gospodarki wodnej na terenie Krakowa oraz istotę ich rozwijania.

Słowa kluczowe: dziedzictwo kulturowe, jakość życia, jakość przestrzeni, rozwiązania oparte na naturze (NBS), sieć rzeczna 